\title{
Growth inhibition of luteolin on HepG2 cells is induced via 553 and Fas/Fas-ligand besides the TGF- $\beta$ pathway
}

\author{
SU BOG YEE ${ }^{1}$, HYE JOUNG CHOI ${ }^{2}$, SANG WOON CHUNG ${ }^{2}$, DONG HEUN PARK ${ }^{3}$, \\ BOKYUNG SUNG ${ }^{2}$, HAE YOUNG CHUNG ${ }^{2}$ and NAM DEUK KIM ${ }^{2}$ \\ ${ }^{1}$ Department of Clinical Laboratory Science, College of Nursing and Healthcare Sciences, Dong-Eui University, \\ Busan 614-714; ${ }^{2}$ Department of Pharmacy, Molecular Inflammation Research Center for Aging Intervention, \\ Pusan National University, Busan 609-735; ${ }^{3}$ School of Medicine, Korea University, Seoul 136-701, Republic of Korea
}

Received April 8, 2015; Accepted June 2, 2015

DOI: 10.3892/ijo.2015.3053

\begin{abstract}
Flavonoids, a class of natural polyphenolic compounds, inhibit cell cycle progression and induce apoptosis. This study was performed to investigate the antiproliferative effect of luteolin, the flavonoid isolated from Ixeris sonchifolia Hance, and to elucidate the detailed apoptotic mechanism in HCC cells. According to the result of MTT assay luteolin possessed antiproliferative effect, and HepG2 cells were the most sensitive to luteolin. Propidium iodide staining, fluorescence activated cell sorting analysis, western blot analysis and RT-PCR were applied to compare the difference of apoptotic event between the two HCC cell lines, with wild-type p53 (HepG2) or not (Hep3B) based on time and concentration. The treatment of luteolin upregulated the expression levels of transforming growth factor $\beta 1$ (TGF- $\beta 1), \mathrm{p} 21^{\mathrm{WAF} 1 / \mathrm{CIP} 1}, \mathrm{p} 27^{\mathrm{KIP} 1}$, Smad4, and Fas in HCC cells. Thus, the expression of $\mathrm{p} 21^{\mathrm{WAF} 1}$ ${ }^{\mathrm{CIP} 1}$ was controlled by another factor, such as TGF- $\beta 1$ in addition to p53, and notably the key factor might be p21 ${ }^{\mathrm{WAF} 1 / \mathrm{CIP} 1}$ in the remarkable switch to $G_{1}$ cell cycle arrest in HepG2 cells rather than $\mathrm{p} 27^{\mathrm{KIP} 1}$. Luteolin induced apoptotic cell death in Hep3B cells while caused G1 arrest in HepG2 cells. Taken together, we conclude that luteolin induces apoptosis from G1 arrest via three signaling pathways of TGF- $\beta 1$, p53, and Fas/ Fas-ligand in HCC cells.
\end{abstract}

\section{Introduction}

Several polyphenolic compounds are known as cancer chemopreventive agents $(1,2)$. Flavonoids are a class of natural polyphenolic compounds, ubiquitously occurring and widely consumed secondary metabolites of plants and have profound

Correspondence to: Dr Nam Deuk Kim, Department of Pharmacy, College of Pharmacy, Pusan National University, 2 Busandaehak-ro 63beon-gil, Geumjeong-gu, Busan 609-735, Republic of Korea

E-mail: nadkim@pusan.ac.kr

Key words: luteolin, HepG2, TGF- $\beta 1$, p53, Fas/FasL, G1 arrest, apoptosis pharmacological properties (3-7). They are reported to have antiviral (8), antiparasitic (9) and anticancer (10-12) activities. Flavonoids suppress cancer cell proliferation (13), arrest cell cycle progression (14), and induce apoptosis (15). Luteolin (3',4',5,7-tetrahydroxyflavone) is an important member of the $>4,000$ different flavonoids family and is present in various fruits and vegetables. Luteolin is reported to have anti-inflammatory and/or anti-allergic activities $(6,16)$, antibacterial (17) and antineoplastic activities (18). It is reported that luteolin of artichoke leaf extract has antioxidant activity on reactive oxygen species in human leucocytes (19) and $\beta$-glucosidase-dependent liberation of luteolin from artichoke extracts inhibits hepatic cholesterol biosynthesis (20). Luteolin also inhibits the growth of a variety of cancer cells including esophageal squamous carcinoma cells (21) and pancreatic (22), gastric (23) and prostate (24) cancer.

How luteolin exhibits its antitumor effects is not fully understood, but various mechanisms including its ability to bind and suppress topoisomerases I and II (25), inhibit cytochrome P450 (CYP) 1 family enzymes (26) and protein kinase C (27), regulate cell cycles (28), induce proapoptotic Fas (29), and increase $\mathrm{Bax} / \mathrm{Bcl}-\mathrm{xL}$ ratio (30) have been implicated. However, detailed mechanism of luteolin-induced apoptosis and chemosensitization in hepatoma cell lines as cancer chemopreventive agents has been infrequently studied up to date. Hepatocellular carcinoma (HCC) is the fifth most common cancer with the highest incidence of adult malignancy evident in areas in which hepatitis B virus is endemic (31) and is the second commonest fatal cancer in Southeast Asia. Most patients usually present in the advanced stage when operation is no longer feasible.

Luteolin (3',4',5,7-tetrahydoxyflavone), isolated from Ixeris sonchifolia Hance, has been reported to possess an antiproliferative effect via G1 cell cycle arrest on HepG2 human HCC cells (32). We also previously reported that luteolin downregulated expression of cyclin-dependent kinase (CDK) 4 and upregulated p53 and CDK inhibitor p21 ${ }^{\mathrm{WAF} 1 / \mathrm{CIP} 1}$, leading to growth inhibition (32). In this study we investigated in detail the p53 contributed apoptotic mechanism, which luteolininduced in HepG2 cells, we checked the antiproliferative effect and chemopreventive machineries of luteolin on HepG2 and Hep3B cells. 


\section{Materials and methods}

Compounds. Flavonoid compounds, luteolin (3',4',5,7-tetrahydoxyflavone) and apigenin (4',5,7-trihydroxyflavone) were purchased from Sigma-Aldrich Co. LLC (St. Louis, MO, USA). Each compound was dissolved in dimethyl sulfoxide (DMSO, Sigma-Aldrich Co. LLC) to $20-200 \mu \mathrm{g} / \mathrm{ml}$ stock solutions for further experiments.

Cell lines and treatment with compounds. Human HCC cell line HepG2 and Hep3B, and human hepatocyte-derived Chang liver cells were obtained from American Type Culture Collection (Manassas, VA, USA). HepG2 and Hep3B were maintained in minimum essential medium (MEM, Invitrogen Life Technologies, Carlsbad, CA, USA) with 10\% fetal bovine serum (FBS, Invitrogen Life Technologies) and antibiotics $(100 \mathrm{U} / \mathrm{ml}$ of penicillin and $100 \mu \mathrm{g} / \mathrm{ml}$ streptomycin, Invitrogen Life Technologies). Chang liver cells were maintained with RPMI-1640 (Invitrogen Life Technologies) supplemented with $10 \%$ FBS with antibiotics in humidified atmosphere of $37^{\circ} \mathrm{C}$, $5 \% \mathrm{CO}_{2}$.

MTT assay. Each cell type $\left(0.96 \times 10^{4}\right.$ cells/well) was seeded in Falcon 96-well plate for MTT assay, which measures mitochondrial activity in viable cells. This method is based on the conversion of the 3-(4,5-dimethylthiazol-2-yl)2,5-diphenyltetrazolium bromide (MTT, Sigma-Aldrich Co. LLC) to MTT-formazan crystals by mitochondrial enzyme. Cells were grown overnight, and the media were replaced with fresh media, treated with each compound at various concentrations, and incubated for $48 \mathrm{~h}$. Control groups were treated with DMSO, equal to the highest percentage $(<0.1 \%)$ of solvent used in experimental conditions for growth inhibition and MTT assay. After $48 \mathrm{~h}$ the media were replaced with serum-free media. MTT was freshly prepared at $5 \mathrm{mg} / \mathrm{ml}$ in phosphate-buffered saline (PBS, Sigma-Aldrich Co. LLC) and passed through a $0.2-\mu \mathrm{m}$ pore-size filter. An aliquot of $100 \mu \mathrm{l}$ of MTT stock solution was added to each well, and the plate was incubated at $37^{\circ} \mathrm{C}$ for $4 \mathrm{~h}$ in humidified $5 \% \mathrm{CO}_{2}$ incubator. After $4 \mathrm{~h}$ media were removed. Ethanol-DMSO (1:1 mixture solution) $(200 \mu \mathrm{l})$ was added per well in order to solubilize the formazan. In addition, after 10 min the optical density of each well was measured with a spectrophotometer equipped with a 560-nm filter. Proliferation rate was calculated from 4 wells using percentage of control.

Fluorescence activated cell sorting (FACS) analysis. The treated cells were detached using trypsin/EDTA (Invitrogen Life Technologies), washed with PBS and fixed in $75 \%$ ethanol at $4^{\circ} \mathrm{C}$ for $30 \mathrm{~min}$. Prior to analyses, cells were washed again with PBS, resuspended in cold PI solution (PI in PBS, $50 \mu \mathrm{g} / \mathrm{ml}$ ) and incubated at room temperature in the dark for $30 \mathrm{~min}$. Before analysis cell suspensions were filtered with $40-\mu \mathrm{m}$ pore nylon mesh for removing debris. Flow cytometry analyses were performed on a FACScan (Becton-Dickinson, San Jose, CA, USA).

Western blot analysis. Cells were harvested and washed twice in PBS at $4^{\circ} \mathrm{C}$. Total cell lysates were lysed in lysis buffer [40 mM Tris (pH 8.0), $120 \mathrm{mM} \mathrm{NaCl}, 0.5 \%$ NP-40, $0.1 \mathrm{mM}$
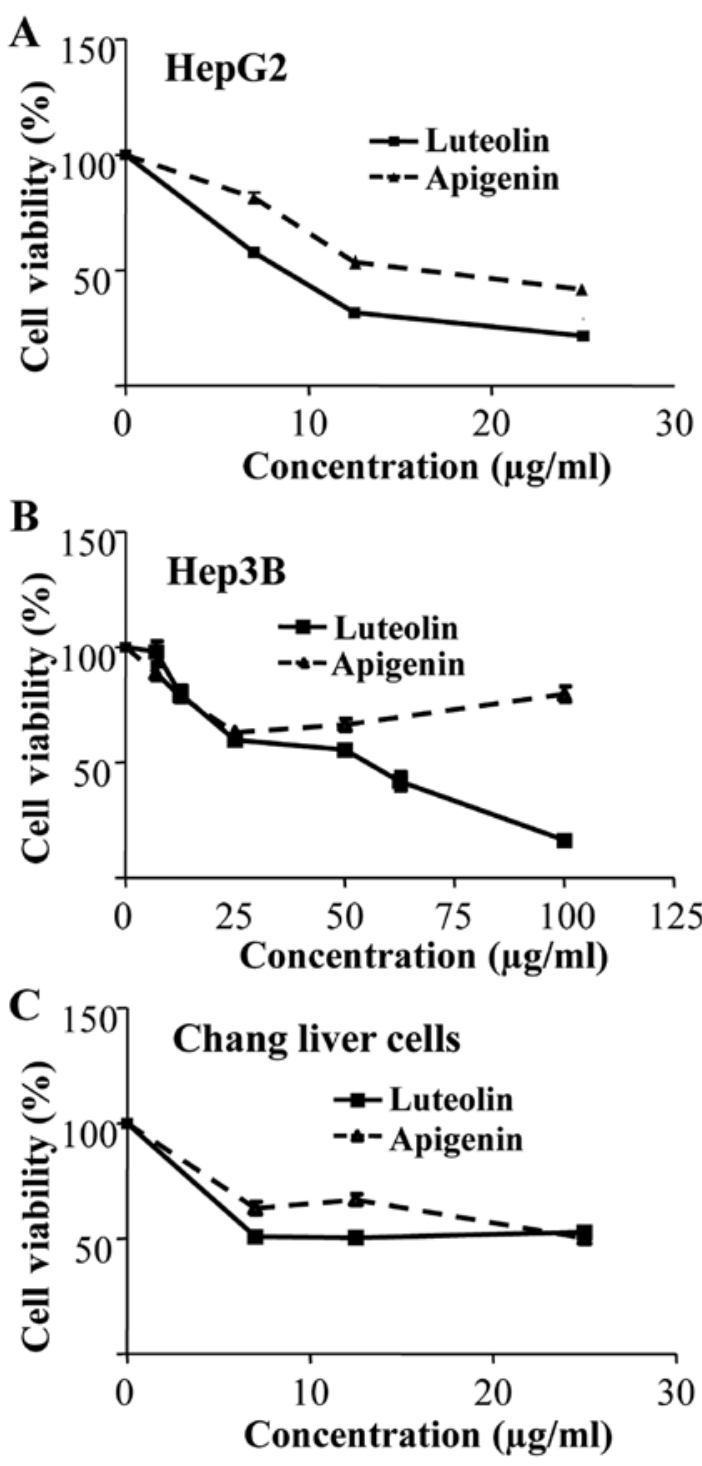

Figure 1. Effect of luteolin and apigenin on the proliferation of HepG2, Hep3B and Chang liver cells. Cells were treated with increasing concentrations of luteolin or apigenin for $48 \mathrm{~h}$. Proliferation was determined with a 3-(4,5-dimethylthiazol-2-yl)-2,5-diphenyl tetrazolium bromide (MTT) assay. The results are expressed as mean \pm standard deviation $(\mathrm{SD} ; \mathrm{n}=3)$ and as a percentage of the vehicle-treated control.

sodium orthovanadate, $2 \mu \mathrm{g} / \mathrm{ml}$ aprotinin]. The supernatant was collected and protein concentrations were then measured with protein assay reagents (Pierce, Rockford, IL, USA). Equal amount of proteins were boiled for $3 \mathrm{~min}$ and chilled on ice, subjected to $10-12.5 \%$ SDS-PAGE, and electrophoretically transferred to a nitrocellulose membrane. The blotting membrane was blocked with PBS/0.1\% Tween-20 containing $10 \%$ skim milk for $1 \mathrm{~h}$. Antibodies specific for $\mathrm{p} 21^{\mathrm{WAF} / \mathrm{CIP} 1}$, p53, p27 ${ }^{\mathrm{KIP} 1}$, B-cell lymphoma 2 (Bcl-2), cyclin E, CDK2, caspase-3, Fas, Fas-ligand (FasL), c-Myc, Bcl-2 associated $\mathrm{X}$ protein (Bax), poly(ADP-ribose) polymerase (PARP), and Smad 4 were purchased from Santa Cruz Biotechnology Inc. (Dallas, TX, USA). Antibody against c-Jun was obtained from BD Biosciences Pharmingen (San Diego, CA, USA). Monoclonal antibody to $\beta$-actin (Sigma-Aldrich Co. LLC) was used as an internal control. Horseradish peroxidase (HRP)- 


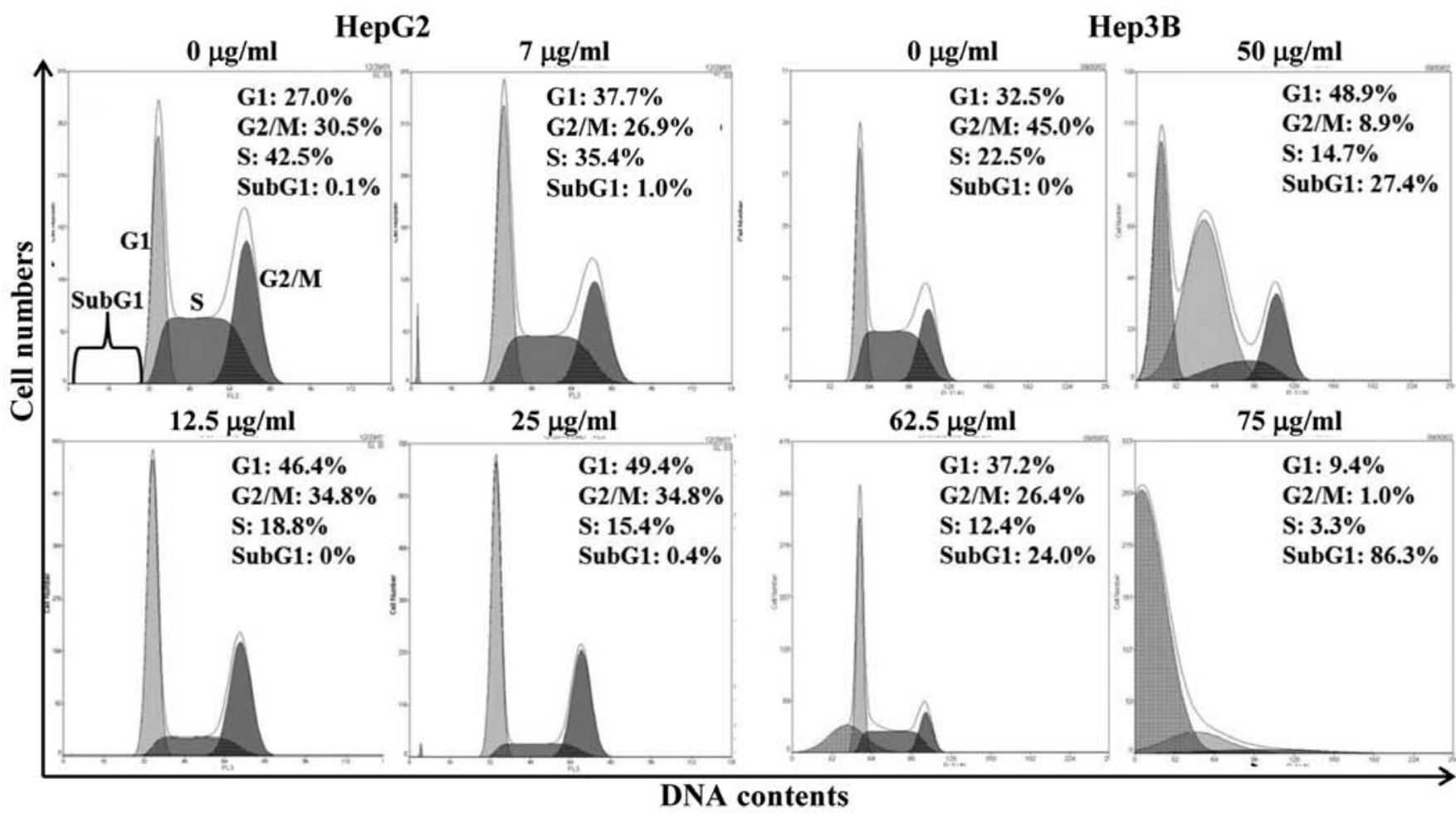

Figure 2. Effect of luteolin on the cell cycle in HCC cells. The cells were, respectively, treated with indicated concentration of luteolin for $12 \mathrm{~h}$. The percentages of cells in sub-G1, G1, S or G2/M phases of cell cycle are indicated within each histogram. Results represent three independent experiments.

labeled donkey anti-rabbit immunoglobulin and HRP-labeled donkey anti-goat immunoglobulin were purchased from Santa Cruz Biotechnology. The HRP-labeled sheep anti-mouse immunoglobulin was from GE Healthcare Life Sciences (Piscataway, NJ, USA). The proteins were visualized with the enhanced chemiluminescence (ECL) detection system (GE Healthcare Life Sciences).

Reverse transcription-polymerase chain reaction (RT-PCR) analysis. Total RNA was prepared using RNAzol (Teltest, Finewood, TX, USA). The reverse transcriptase (RT) reaction was carried out with SuperScript II reverse transcriptase (Life Technologies). The RT reaction mixture containing $1 \mu \mathrm{g}$ total RNA, 100 pmol oligo (dT) $)_{18}, 0.1 \mathrm{mM}$ dNTP mixture, $40 \mathrm{U}$ RNasin ribonuclease inhibitor (Progmega, Madison, WI, USA), 5X First-strand buffer and 200 U SuperScript II reverse transcriptase (Life Technologies). The synthesis of cDNA was performed at $42^{\circ} \mathrm{C}$ for $1 \mathrm{~h}$, followed by $15 \mathrm{~min}$ of heating at $70^{\circ} \mathrm{C}$ for inactivating enzyme. A final volume of $20 \mu \mathrm{l}$ of reaction containing $1 \mu \mathrm{l}$ of template cDNA from RT reaction, $20 \mathrm{pmol}$ of sense and antisense primers, $2 \mu \mathrm{l}$ of 10X PCR buffer, $0.5 \mathrm{mM}$ of dNTP mixtur, and $1 \mathrm{U}$ of AmpliTaq polymerase (PE Biosystem, Waltham, MA, USA) was carried out on a GeneAmp PCR System 2400 (PE Biosystem). The primer sequence is as follows (33); transforming growth factor $\beta 1$ (TGF- $\beta 1$ ) sense 5'-GCCCTGGACACCAACTATTGCT-3', TGF- $\beta 1$ antisense 5'-AGGCTCCAAATGTAGGGGCAGG-3'. PCR reaction performed was denature at $94^{\circ} \mathrm{C}$ for $40 \mathrm{sec}$, annealing at $64^{\circ} \mathrm{C}$ for $45 \mathrm{sec}$, and extension at $72^{\circ} \mathrm{C}$ for $45 \mathrm{sec}$, and 35 cycles were used for amplification. The amplified PCR products were electrophoresed on $2.5 \%$ agarose gels and visualized by ethidium bromide staining.

\section{Results}

Luteolin inhibits the growth of human hepatocellular cells. To examine the growth inhibitory potency of luteolin on hepatocellular cells, cell proliferation was determined by MTT assay. We also employed apigenin to examine cell proliferation since luteolin and apigenin were identified as active components in Ixeris sonchifolia Hance, and luteolin showed a significant potent effect when comparing their ability on growth inhibition (32). Luteolin was more potent than apigenin in all the cell lines tested in the present study (Fig. 1). In addition, HepG2 was the most sensitive to luteolin (Fig. 1A). $\mathrm{IC}_{50}$ values of luteolin on HepG2 and Hep3B cells were $\sim 9$ and $55 \mu \mathrm{g} / \mathrm{ml}$, respectively (Fig. 1A and B). On Chang liver cells, no significant antiproliferative effect was observed in either luteolin or apigenin treatment (Fig. 1C).

Luteolin induces G1 phase arrest in HepG2 cells and apoptosis in Hep3B cells. To determine whether luteolin's growth inhibitory effect was caused by specifically perturbing cell cycle-related events, a set of experiment was performed to measure DNA content and the cell cycle distribution by flow cytometry analysis after staining with PI. Fig. 2 shows the relative percentages of HepG2 and Hep3B cells in each phase of the cell cycle, following a 12-h treatment with varying luteolin concentrations. In HepG2 cells, luteolin induced the accumulation of G1 phase of cell cycle in a concentration-dependent manner (Fig. 2, left panel). However, Hep3B cells showed increase of subG1 population at the same time-point (Fig. 2, right panel). These results suggest that the growth inhibition of HepG2 cells was the result of a G1 phase arrest and that of Hep3B cells occurred mainly through apoptosis. 


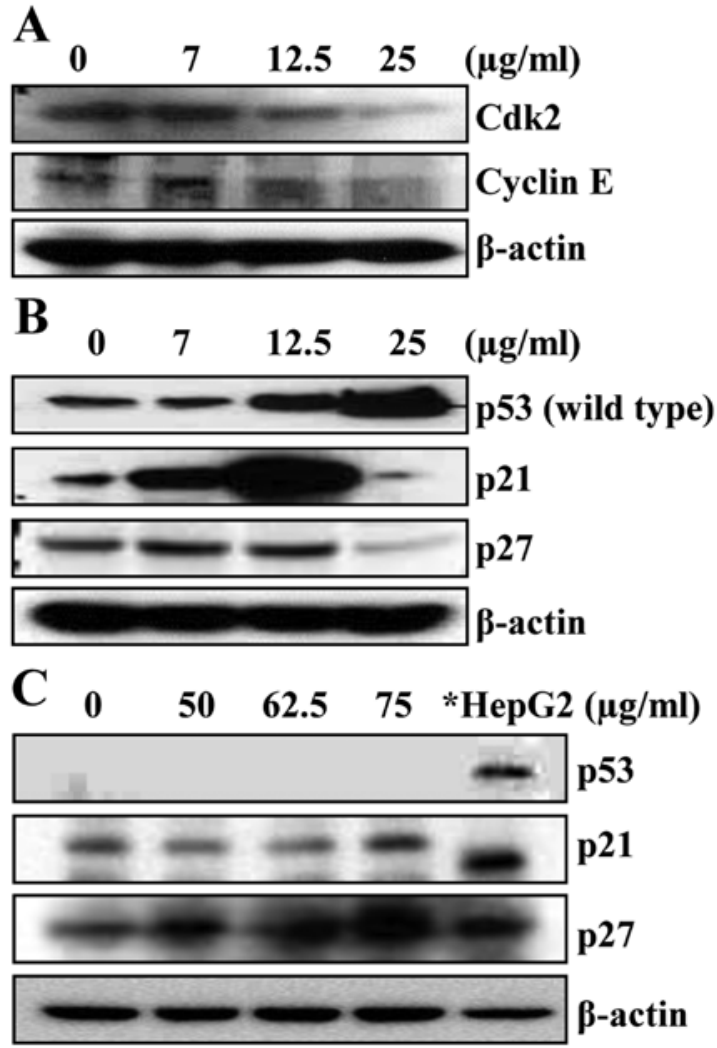

Figure 3. Effect of luteolin on the cell cycle regulatory proteins in HCC cells. HepG2 cells (A and B) and Hep3B cells (C) were treated with increasing concentrations of luteolin for $24 \mathrm{~h}$. The cells were lysed, and the levels of indicated proteins were analyzed by western blot analysis. "Total lysate from untreated HepG2 was used as a positive control for p53. Results represent three independent experiments.

Luteolin modulates cell cycle regulatory proteins. Since luteolin arrested HepG2 cells in the G1 phase of the cell cycle, we determined the expression levels of cell cycle regulating factors involved in G1 boundary, such as cyclin E and Cdk2, by western blot analysis. As shown in Fig. 3A, the protein levels of cdk 2 and cyclin $\mathrm{E}$ were decreased in a concentration-dependent manner. These data indicate that the growth inhibitory effect of luteolin in HepG2 cells are caused by downregulating cdk 2 and cyclin E expression.

Luteolin induced $p 21^{\text {WAFI/CIPI }}$ and G1 arrest in a p53-independent manner. Because it has been reported that $\mathrm{p} 53$, a tumor suppressor, regulates a DNA damage-triggered G1 checkpoint by upregulation of CDK inhibitor $\mathrm{p} 21^{\mathrm{WAF} 1 / \mathrm{CIP} 1}$ (34), we examined the expression patterns of $\mathrm{p} 53$ and $\mathrm{p} 21^{\mathrm{WAF} 1 / \mathrm{CIP} 1}$ by luteolin-treatment. As shown in Fig. 3B, HepG2 cells treated with luteolin increased the expression of p53 in a concentrationdependent manner. Unlike p53, the concentrations of luteolin ranging from 7 to $12.5 \mu \mathrm{g} / \mathrm{ml}$ markedly increased the protein level of $\mathrm{p} 21^{\mathrm{WAF} / \mathrm{CIP} 1}$; however, this induction of $\mathrm{p} 21^{\mathrm{WAF} 1 / \mathrm{CIP} 1}$ was decreased at $25 \mu \mathrm{g} / \mathrm{ml}$ luteolin (Fig. 3B). This result is consistent with our previous study which was performed by using luteolin from Ixeris sonchifolia Hance (32). Because p27 ${ }^{\mathrm{KIP} 1}$, another CDK inhibitor, is reported to arrest cells only at the G1 phase $(35,36)$, we next determined the effect of luteolin on p2 $7^{\mathrm{KIP} 1}$ expression. HepG2 cells treated with luteolin showed
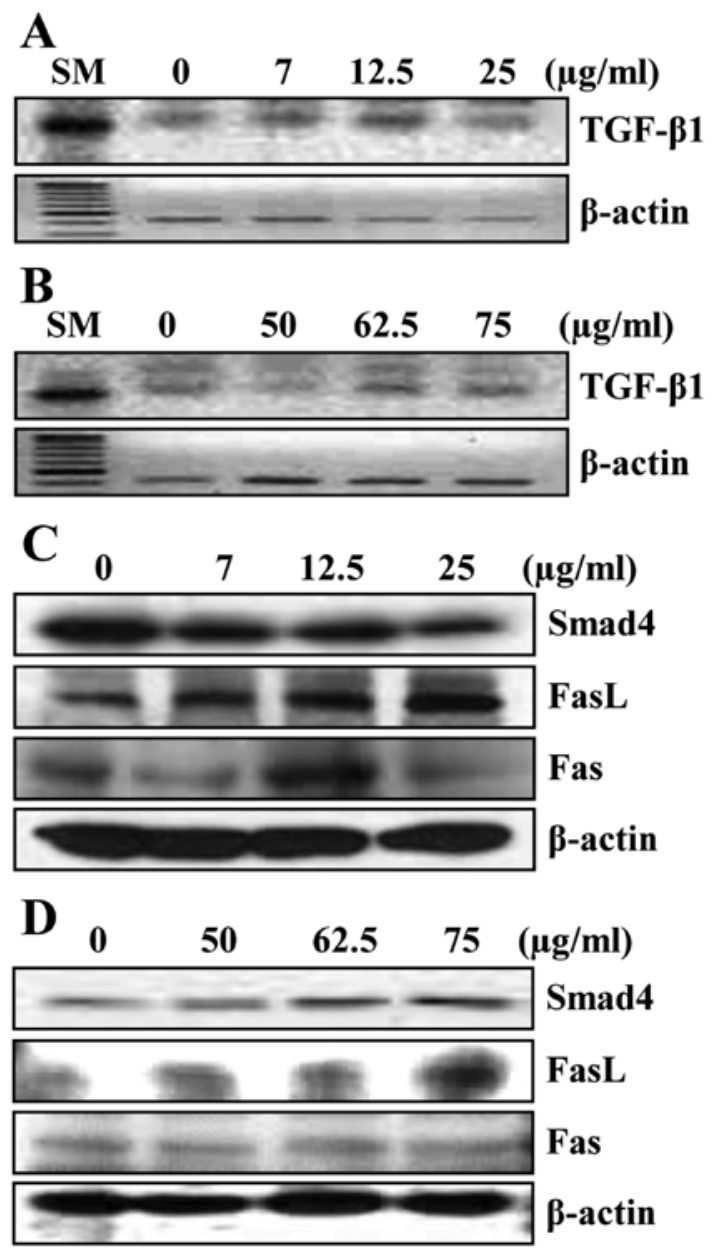

Figure 4. Effect of luteolin on cell cycle regulatory TGF- $\beta 1$ and cell deathrelated signals in HCC cells. HepG2 cells (A and C) and Hep3B cells (B and D) were treated with indicated concentration of luteolin for $24 \mathrm{~h}$ (A and B) The mRNA level of TGF- $\beta 1$ was analyzed by RT-PCR. SM, size marker (25/100 bp mixed DNA ladder). (C and D) The cells were lysed, and the levels of smad4, FasL and Fas proteins were analyzed by western blot analysis. Results represent three independent experiments.

similar expression pattern of $\mathrm{p} 27^{\mathrm{KIP} 1}$ compared with that of $\mathrm{p} 21^{\mathrm{WAF} / \mathrm{CIPl}}$ although there was no prominent increase at $12.5 \mu \mathrm{g} / \mathrm{ml}$ luteolin (Fig. 3B). These results suggest that other factors besides p53 may be involved in luteolin-induced G1 arrest as well as growth inhibition in HepG2 cells.

To further confirm our hypothesis that other mechanisms are involved in luteolin-induced HCC cell growth inhibition, we examined the effect of luteolin on $\mathrm{p} 53, \mathrm{p} 21^{\mathrm{WAF} 1 / \mathrm{CIP} 1}$, and p2 $7^{\mathrm{KIP1}}$ expressions using P53-deleted HCC Hep3B cells. As expected, no p53 expression was observed in Hep3B cells (Fig. 3C). However, treatment of Hep3B cells with luteolin resulted in a concentration-dependent increase in the expression of $\mathrm{p} 21^{\mathrm{WAF} / \mathrm{CIP} 1}$ and $\mathrm{p} 27^{\mathrm{KIP} 1}$ (Fig. 3C). These results from HepG2 and Hep3B cells suggest that the mechanism(s) other than $\mathrm{p} 53$ may be involved in the upregulation of $\mathrm{p} 21^{\mathrm{WAF} 1 / \mathrm{CIP} 1}$ by luteolin.

Luteolin modulated the expression of TGF- $\beta 1$ and Fas/FasL in HCC cells. Transforming growth factor $\beta 1$ (TGF- $\beta 1$ ) is an essential regulator of cellular processes including prolifera- 

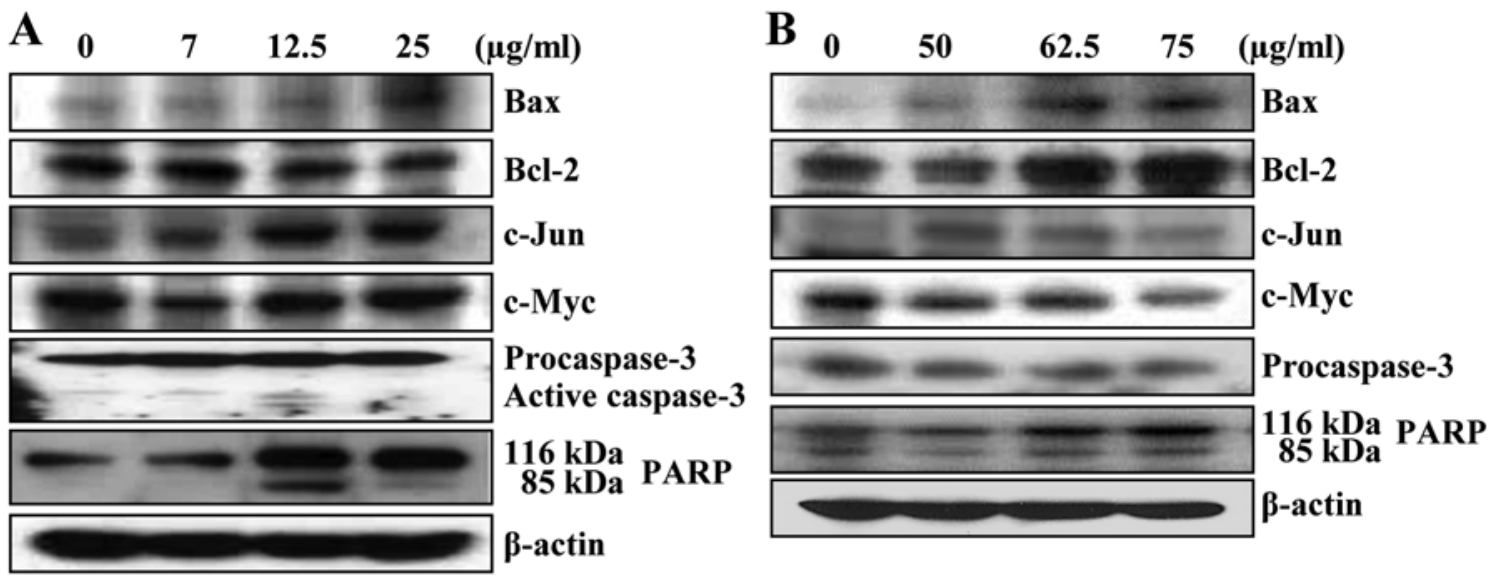

Figure 5. Effects of luteolin on mitochondrial-related apoptotic proteins. HepG2 cells (A) and Hep3B cells (B) were treated with indicated concentration of luteolin for $24 \mathrm{~h}$. The cells were lysed, and the levels of indicated proteins were analyzed by western blot analysis. Results represent three independent experiments.

tion, differentiation, migration, cell survival and angiogenesis. TGF- $\beta 1$ has been reported to exert its function via specific receptors and intracellular Smad transcription factors. Phosphorylation of receptor-activated Smads, such as Smad2 or Smad3, leads to formation of complexes with the common mediator Smad (Smad4), which are imported to the nucleus, induce cycle-dependent kinase inhibitors, and then lead to G1 arrest (37). Therefore, TGF- $\beta 1$ is known as an upstream G1 arrest signal $(34,36)$. Whether luteolin affects the expression of TGF- $\beta 1$ and Smad4 in HCC cells was examined. The mRNA level of TGF- $\beta 1$ was gradually increased by luteolin treatment in HepG2 cells (Fig. 4A). Treatment with various concentrations of luteolin also induced the mRNA level of TGF- $\beta 1$ in Hep3B cells (Fig. 4B).

We next tested the effect of luteolin on Smad4 expression in HCC cells. Results show that Smad4 expression level in HepG2 cells slightly increased at $12.5 \mu \mathrm{g} / \mathrm{ml}$ and decreased at $25 \mu \mathrm{g} / \mathrm{ml}$ concentration of luteolin (Fig. 4C). In Hep3B cells, luteolin treatment increased Smad4 expression concentrationdependently (Fig. 4D).

Because TGF- $\beta 1$ signaling is reported to activate Fas-mediated apoptotic pathways (38), we investigated whether luteolin affects the expression of Fas and its ligand FasL in HCC cells. Fig. 4C shows that luteolin upregulated FasL in a concentration-dependent manner, but Fas increased up to $12.5 \mu \mathrm{g} / \mathrm{ml}$, then decreased at $25 \mu \mathrm{g} / \mathrm{ml}$ in HepG2 cells. We also observed similar expression pattern of FasL in Hep3B cells although Fas was not significantly altered by luteolin (Fig. 4D).

Luteolin triggered apoptosis through proapoptotic Bax. To confirm the contribution of Fas/FasL and p53 on luteolininduced apoptosis, we investigated whether the expression of apoptotic protein Bax, Bcl-2, caspase-3 and PARP, were modulated by luteolin. Luteolin treatment increased Bax and slightly decreased Bcl-2 expression in a concentration-dependent manner in HepG2 cells (Fig. 5A). Luteolin also increased Bax expression in Hep3B cells (Fig. 5B). In contrast, Bcl-2 level was increased simultaneously in Hep3B cells by luteolin (Fig. 5B). To elucidate the mechanism of Bcl-2 upregulation by luteolin in Hep3B cells, we determined the effect of luteolin on oncogene expression, such as c-Jun and c-Myc. An increase of c-Myc and c-Jun expression was observed in HepG2 cells (Fig. 5A); however, the reduction of these proteins was found in Hep3B cells (Fig. 5B).

Finally, the pro-caspase-3 level and PARP cleavage were measured in luteolin-treated HCC cells. In the presence of lutein, the increase of cleavage forms of caspase- 3 and PARP were observed in HepG2 cells (Fig. 5A). Similarly, PARP cleavage was detected in Hep3B cells in a concentrationdependent manner and pro-form of caspase-3 decreased slightly (Fig. 5B).

\section{Discussion}

In the present report, we investigated how luteolin induces cell death on HCC cell line HepG2 and Hep3B cells. Luteolin elicited G1 cell cycle arrest in HepG2 and direct apoptosis on Hep3B cells. Interestingly in the comparative experiment between HepG2 and Hep3B cells with various concentration of luteolin, we found that luteolin induced cell cycle arrest on HepG2 cells by orchestration of three signaling pathways; TGF- $\beta$, p53 and Fas/FasL.

It has been reported that $\mathrm{p} 27^{\mathrm{KIP} 1}$ arrests cells only at the Gl phase compared to $\mathrm{p} 21^{\mathrm{WAF} / \mathrm{CIP} 1}$ which regulates $\mathrm{G} 1$ and $\mathrm{G} 2$ phases $(35,36)$. In the present study, the expression of $\mathrm{p} 27^{\mathrm{KIP} 1}$ on HepG2 was not remarkably changed in comparison with the vehicle-treated control, and decreased at high concentration of $25 \mu \mathrm{g} / \mathrm{ml}$. Interestingly the level of p $21^{\mathrm{WAF} / \mathrm{CIP} 1}$ dramatically increased up to $12.5 \mu \mathrm{g} / \mathrm{ml}$ and decreased at $25 \mu \mathrm{g} / \mathrm{ml}$. This fact suggests that $\mathrm{p} 21^{\mathrm{WAF} / \mathrm{CIP} 1}$ may be a key factor in the G1 cell cycle arrest of HepG2 rather than $\mathrm{G} 2 / \mathrm{M}$ arrest around at the $\mathrm{IC}_{50}$ and we observed increased amount of cells treated with $12.5 \mu \mathrm{g} / \mathrm{ml}$ luteolin under $\mathrm{G} 2 / \mathrm{M}$ phase for $24 \mathrm{~h}$.

$\mathrm{Smad} 4$ has been reported to form heteromeric complexes with Smad2 and Smad3, and these complexes are translocated to the nucleus, bind to DNA in sequence specific manner, and regulate gene transcription (37). These complexes induce cycle-dependent kinase inhibitors $116^{\mathrm{INK} 4}, \mathrm{p} 15^{\mathrm{INK} 4}, \mathrm{p} 27^{\mathrm{KIP} 1}$ and $\mathrm{p} 21^{\mathrm{WAF} 1 / \mathrm{CIP} 1}$ to increase, finally leading to $\mathrm{G} 1$ arrest $(39,40)$. 


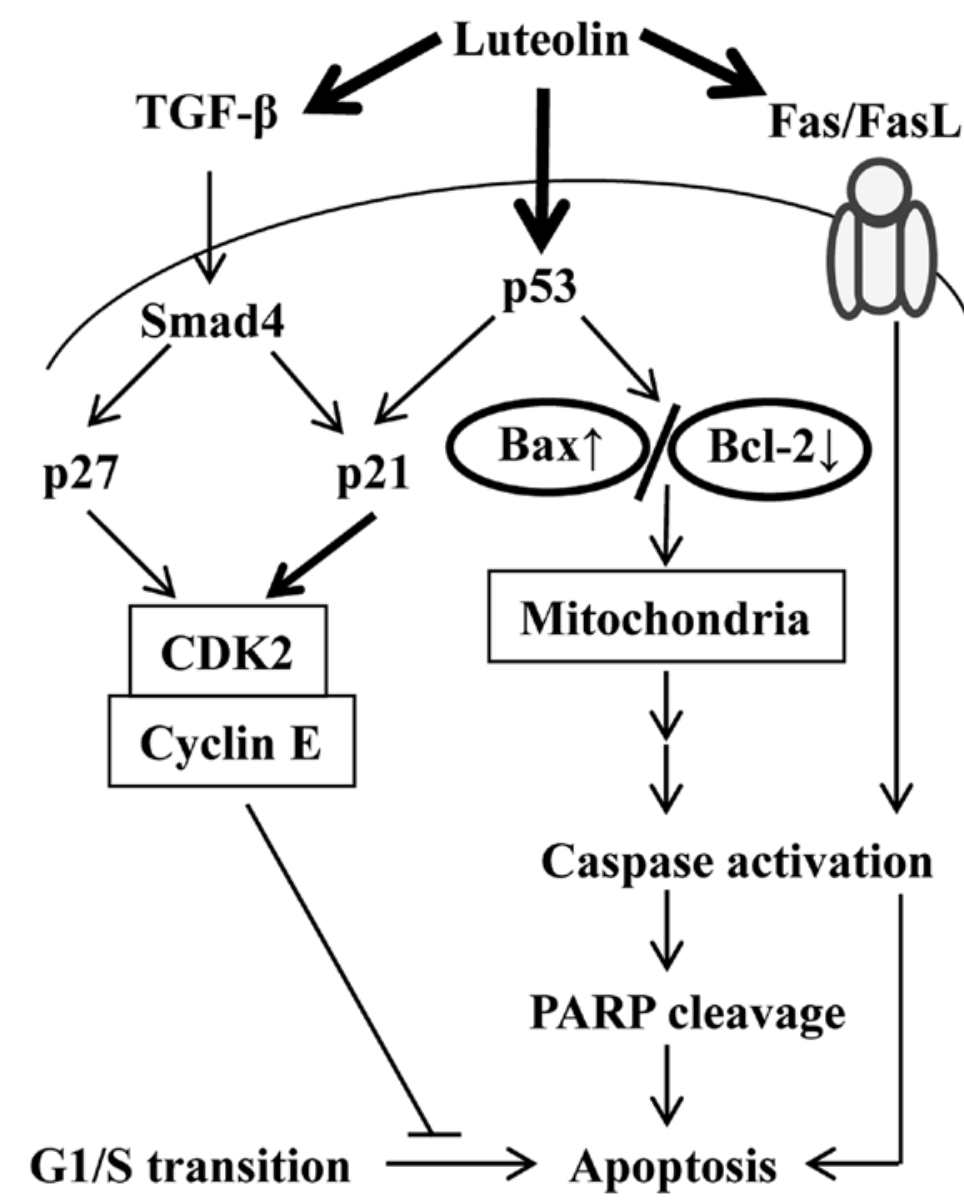

Figure 6. Proposed mechanism of luteolin-induced cell cycle arrest and apoptosis in HepG2 cells. The thickest arrows present the first signals affected by luteolin. Each closed line and arrow indicate inhibitory and inducing effect to apoptosis.

In addition, it is ascertain whether TGF- $\beta$ is the upstream signal of Smad4 (41), so we investigated mRNA expression of TGF- $\beta 1$ to confirm that TGF- $\beta 1$ might be associated with this luteolin-induced G1 phase cell cycle arrest. We also found that the expression pattern of TGF- $\beta 1$ by luteolin treatment was similar to the protein expression pattern of Smad4, which suggest that one possible pathway of luteolin-induced G1 phase arrest may due to TGF- $\beta 1$ signaling. Polyak et al (35) reported that TGF- $\beta 1$ induces arrest of the cell cycle in G1. Our results in the present study are relevant to this previous report and suggest that TGF- $\beta 1$ plays a role in luteolin-mediated G1 arrest via regulation of $\mathrm{p} 21^{\mathrm{WAF} / \mathrm{CIP} 1}$ and $\mathrm{p} 27^{\mathrm{KIP} 1}$.

Furthermore, our results demonstrated that p53 might not be crucial for luteolin-induced apoptosis in HCC cells. The results from the comparative study between HepG2 and Hep3B cells suggested that luteolin was able to induce cell death through p53-independent pathways. This was in agreement with previous observations by others in esophageal squamous cell carcinoma and prostate cancer cells $(42,43)$.

One of the possible mechanisms for the luteolin-induced apoptotic cell death is through Fas/FasL pathway. In our observations, luteolin-induced Fas expression was accompanied by p53-induced caspase-3 activation and PARP cleavage, which are hallmarks of apoptosis. In addition, luteolin treatment decreased Bcl-2, a negative regulator of Fas-induced apoptosis. Bcl-2 provides a true survival advantage after many diverse stimuli, including chemotherapeutic agents, $\gamma$-radiation and growth factor deprivation (44). It was reported that Bcl-2 exerts the ability to counter apoptosis elicited by Myc under suboptimal growth conditions, and Myc has the ability to override the retardation of cell-cycle entry by Bcl-2 $(45,46)$. The contrary effect between Myc and Bcl-2 to apoptosis, and the increased Bcl-2 protein did not allow Hep3B cells to enter the cell cycle arrest. Also it is reported that overexpressed $\mathrm{Bcl}-2$ resulted in a significant rise in $\mathrm{p} 21^{\mathrm{WAF} / \mathrm{CIP} 1}$ in endometrial carcinoma cells (47), from this viewpoint, it might be possible that increased Bcl-2 impinges on Hep3B cells increasing p $21^{\mathrm{WAF} 1 / \mathrm{CIP} 1}$ expression compared to HepG2 cells and cannot play a role for cell survival. Our results demonstrated that luteolin-triggered apoptosis in Hep3B cells might result from continuous increase of TGF- $\beta 1$ and Fas protein, and despite the increase of Fas/FasL, Bcl-2 expression increased concentration-dependently, this seems to be caused by the decrease of myc protein.

Taken together, our study demonstrates that luteolin induced G1 phase arrest via TGF- $\beta 1$, Fas/FasL, and p53 signaling pathway on HepG2 cells (Fig. 6), and the strength of these signals is changeable according to the administered concentration of luteolin. Also, p2 $1^{\mathrm{WAF} / \mathrm{CIP} 1}$ might be a key protein in the $\mathrm{G} 1$ cell cycle arrest of HepG2 at the $\mathrm{IC}_{50}$, and the $\mathrm{IC}_{50}$ value of luteolin on $\mathrm{HepG} 2$ of this study correspond to our previous report (48). On p53 deleted Hep3B cells, luteolin 
elicited apoptosis directly via TGF- $\beta 1$ and Fas/FasL signaling pathways. On the basis of these results, further studies are required in animals and in patients to explore the potential of luteolin as an anticancer agent for liver cancer patients.

\section{Acknowledgements}

This study was supported by the National Research Foundation of Korea (NRF) grant funded by the Korea government (MSIP) (no. 2009-0083538).

\section{References}

1. Chen D and Dou QP: Tea polyphenols and their roles in cancer prevention and chemotherapy. Int J Mol Sci 9: 1196$1206,2008$.

2. Berdowska I, Zieliński B, Fecka I, Kulbacka J, Saczko J and Gamian A: Cytotoxic impact of phenolics from Lamiaceae species on human breast cancer cells. Food Chem 141: 1313-1321, 2013.

3. Woodman OL and Chan EC: Vascular and anti-oxidant actions of flavonols and flavones. Clin Exp Pharmacol Physiol 31: 786-790, 2004.

4. Russo P, Del Bufalo A and Cesario A: Flavonoids acting on DNA topoisomerases: Recent advances and future perspectives in cancer therapy. Curr Med Chem 19: 5287-5293, 2012.

5. Guerra-Araiza C, Álvarez-Mejía AL, Sánchez-Torres S, Farfan-García E, Mondragón-Lozano R, Pinto-Almazán R and Salgado-Ceballos $\mathrm{H}$ : Effect of natural exogenous antioxidants on aging and on neurodegenerative diseases. Free Radic Res 47: 451-462, 2013.

6. Kritas SK, Saggini A, Varvara G, Murmura G, Caraffa A, Antinolfi P, Toniato E, Pantalone A, Neri G, Frydas S, et al: Luteolin inhibits mast cell-mediated allergic inflammation. J Biol Regul Homeost Agents 27: 955-959, 2013.

7. Sak K: Cytotoxicity of dietary flavonoids on different human cancer types. Pharmacogn Rev 8: 122-146, 2014.

8. Kaul TN, Middleton E Jr and Ogra PL: Antiviral effect of flavonoids on human viruses. J Med Virol 15: 71-79, 1985.

9. Kayser O, Kiderlen AF and Croft SL: Natural products as antiparasitic drugs. Parasitol Res 90 (Suppl 2): S55-S62, 2003.

10. Lin YS, Tsai PH, Kandaswami CC, Cheng CH, Ke FC, Lee PP, Hwang JJ and Lee MT: Effects of dietary flavonoids, luteolin, and quercetin on the reversal of epithelial-mesenchymal transition in A431 epidermal cancer cells. Cancer Sci 102: 1829-1839, 2011.

11. López-Lázaro M: Flavonoids as anticancer agents: Structureactivity relationship study. Curr Med Chem Anticancer Agents 2 : 691-714, 2002

12. Chahar MK, Sharma N, Dobhal MP and Joshi YC: Flavonoids: A versatile source of anticancer drugs. Pharmacogn Rev 5: 1-12, 2011.

13. Kawaii S, Tomono $\mathrm{Y}$, Katase $\mathrm{E}$, Ogawa $\mathrm{K}$ and Yano $\mathrm{M}$ Antiproliferative activity of flavonoids on several cancer cell lines. Biosci Biotechnol Biochem 63: 896-899, 1999.

14. Singh RP and Agarwal R: Natural flavonoids targeting deregulated cell cycle progression in cancer cells. Curr Drug Targets 7: 345-354, 2006

15. Ramos S: Effects of dietary flavonoids on apoptotic pathways related to cancer chemoprevention. J Nutr Biochem 18: 427-442, 2007.

16. Pandurangan AK, Kumar SA, Dharmalingam $\mathrm{P}$ and Ganapasam S: Luteolin, a bioflavonoid inhibits azoxymethaneinduced colon carcinogenesis: Involvement of iNOS and COX-2. Pharmacogn Mag 10 (Suppl 2): S306-S310, 2014

17. Tofighi Z, Molazem M, Doostdar B, Taban P, Shahverdi AR, Samadi N and Yassa N: Antimicrobial activities of three medicinal plants and investigation of flavonoids of tripleurospermum disciforme. Iran J Pharm Res 14: 225-231, 2015.

18. Li YC, Hung CF, Yeh FT, Lin JP and Chung JG: Luteolin-inhibited arylamine $\mathrm{N}$-acetyltransferase activity and DNA-2-aminofluorene adduct in human and mouse leukemia cells. Food Chem Toxicol 39: 641-647, 2001

19. Pérez-García F, Adzet T and Cañigueral S: Activity of artichoke leaf extract on reactive oxygen species in human leukocytes. Free Radic Res 33: 661-665, 2000.
20. Gebhardt R: Inhibition of cholesterol biosynthesis in HepG2 cells by artichoke extracts is reinforced by glucosidase pretreatment. Phytother Res 16: 368-372, 2002.

21. Wang TT, Wang SK, Huang GL and Sun GJ: Luteolin inducedgrowth inhibition and apoptosis of human esophageal squamous carcinoma cell line Eca109 cells in vitro. Asian Pac J Cancer Prev 13: 5455-5461, 2012.

22. Cai X, Lu W, Ye T, Lu M, Wang J, Huo J, Qian S, Wang X and Cao P: The molecular mechanism of luteolin-induced apoptosis is potentially related to inhibition of angiogenesis in human pancreatic carcinoma cells. Oncol Rep 28: 1353-1361, 2012.

23. Lu J, Li G, He K, Jiang W, Xu C, Li Z, Wang H, Wang W, Wang H, Teng X, et al: Luteolin exerts a marked antitumor effect in cMet-overexpressing patient-derived tumor xenograft models of gastric cancer. J Transl Med 13: 42, 2015.

24. Chiu FL and Lin JK: Downregulation of androgen receptor expression by luteolin causes inhibition of cell proliferation and induction of apoptosis in human prostate cancer cells and xenografts. Prostate 68: 61-71, 2008

25. Chowdhury AR, Sharma S, Mandal S, Goswami A, Mukhopadhyay S and Majumder HK: Luteolin, an emerging anti-cancer flavonoid, poisons eukaryotic DNA topoisomerase I. Biochem J 366: 653-661, 2002.

26. Buening MK, Chang RL, Huang MT, Fortner JG, Wood AW and Conney AH: Activation and inhibition of benzo $(a)$ pyrene and aflatoxin B1 metabolism in human liver microsomes by naturally occurring flavonoids. Cancer Res 41: 67-72, 1981.

27. Ferriola PC, Cody V and Middleton E Jr: Protein kinase C inhibition by plant flavonoids. Kinetic mechanisms and structure-activity relationships. Biochem Pharmacol 38: 1617-1624, 1989.

28. Ko WG, Kang TH, Lee SJ, Kim YC and Lee BH: Effects of luteolin on the inhibition of proliferation and induction of apoptosis in human myeloid leukaemia cells. Phytother Res 16: 295-298, 2002.

29. Selvendiran K, Koga H, Ueno T, Yoshida T, Maeyama M, Torimura T, Yano H, Kojiro M and Sata M: Luteolin promotes degradation in signal transducer and activator of transcription 3 in human hepatoma cells: An implication for the antitumor potential of flavonoids. Cancer Res 66: 4826-4834, 2006.

30. Chang J, Hsu Y, Kuo P, Kuo Y, Chiang L and Lin C: Increase of $\mathrm{Bax} / \mathrm{Bcl}-\mathrm{XL}$ ratio and arrest of cell cycle by luteolin in immortalized human hepatoma cell line. Life Sci 76: 1883-1893, 2005.

31. Villanueva A, García C, Paules AB, Vicente M, Megías M, Reyes G, de Villalonga P, Agell N, Lluís F, Bachs O, et al: Disruption of the antiproliferative TGF-beta signaling pathways in human pancreatic cancer cells. Oncogene 17: 1969-1978, 1998.

32. Yee SB, Lee JH, Chung HY, Im KS, Bae SJ, Choi JS and Kim ND: Inhibitory effects of luteolin isolated from Ixeris sonchifolia Hance on the proliferation of HepG2 human hepatocellular carcinoma cells. Arch Pharm Res 26: 151-156, 2003.

33. Derynck R, Jarrett JA, Chen EY, Eaton DH, Bell JR, Assoian RK, Roberts AB, Sporn MB and Goeddel DV: Human transforming growth factor-beta complementary DNA sequence and expression in normal and transformed cells. Nature 316: 701-705, 1985.

34. Hartwell LH and Kastan MB: Cell cycle control and cancer. Science 266: 1821-1828, 1994.

35. Polyak K, Kato JY, Solomon MJ, Sherr CJ, Massague J, Roberts JM and Koff A: p2 $7^{\mathrm{Kip} 1}$, a cyclin-Cdk inhibitor, links transforming growth factor-beta and contact inhibition to cell cycle arrest. Genes Dev 8: 9-22, 1994.

36. Toyoshima H and Hunter T: p27, a novel inhibitor of G1 cyclin-Cdk protein kinase activity, is related to p21. Cell 78: 67-74, 1994.

37. Massagué J: TGF-beta signal transduction. Annu Rev Biochem 67: 753-791, 1998.

38. Kim SG, Jong HS, Kim TY, Lee JW, Kim NK, Hong SH and Bang YJ: Transforming growth factor-beta 1 induces apoptosis through Fas ligand-independent activation of the Fas death pathway in human gastric SNU-620 carcinoma cells. Mol Biol Cell 15: 420-434, 2004.

39. Depoortere F, Pirson I, Bartek J, Dumont JE and Roger PP: Transforming growth factor beta(1) selectively inhibits the cyclic AMP-dependent proliferation of primary thyroid epithelial cells by preventing the association of cyclin D3-cdk4 with nuclear p27(kip1). Mol Biol Cell 11: 1061-1076, 2000.

40. Park BJ, Park JI, Byun DS, Park JH and Chi SG: Mitogenic conversion of transforming growth factor-betal effect by oncogenic Ha-Ras-induced activation of the mitogen-activated protein kinase signaling pathway in human prostate cancer. Cancer Res 60: 3031-3038, 2000. 
41. Nakao A,Imamura T, Souchelnytskyi S, Kawabata M, Ishisaki A, Oeda E, Tamaki K, Hanai J, Heldin CH, Miyazono K, et al: TGF-beta receptor-mediated signalling through Smad2, Smad3 and Smad4. EMBO J 16: 5353-5362, 1997.

42. Zhang Q, Zhao XH and Wang ZJ: Cytotoxicity of flavones and flavonols to a human esophageal squamous cell carcinoma cell line (KYSE-510) by induction of G2/M arrest and apoptosis. Toxicol In Vitro 23: 797-807, 2009.

43. Kobayashi T, Nakata T and Kuzumaki T: Effect of flavonoids on cell cycle progression in prostate cancer cells. Cancer Lett 176: 17-23, 2002.

44. Walker A, Taylor ST, Hickman JA and Dive C: Germinal centerderived signals act with $\mathrm{Bcl}-2$ to decrease apoptosis and increase clonogenicity of drug-treated human B lymphoma cells. Cancer Res 57: 1939-1945, 1997.
45. Cory S, Vaux DL, Strasser A, Harris AW and Adams JM: Insights from Bcl-2 and Myc: Malignancy involves abrogation of apoptosis as well as sustained proliferation. Cancer Res 59 (Suppl): S1685-S1692, 1999.

46. Green DR and Evan GI: A matter of life and death. Cancer Cell 1: 19-30, 2002.

47. Crescenzi E and Palumbo G: Bcl-2 exerts a pRb-mediated cell cycle inhibitory function in HEC1B endometrial carcinoma cells. Gynecol Oncol 81: 184-192, 2001.

48. Attoub S, Hassan AH, Vanhoecke B, Iratni R, Takahashi T, Gaben AM, Bracke M, Awad S, John A, Kamalboor HA, et al: Inhibition of cell survival, invasion, tumor growth and histone deacetylase activity by the dietary flavonoid luteolin in human epithelioid cancer cells. Eur J Pharmacol 651: 18-25, 2011. 